\title{
Virucidal and Synergistic Activity of Polyphenol-Rich Extracts of Seaweeds against Measles Virus
}

\author{
Karla Morán-Santibañez ${ }^{1,2, *(1)}$, Mario A. Peña-Hernández ${ }^{1}$, Lucia Elizabeth Cruz-Suárez ${ }^{3}$ (D), \\ Denis Ricque-Marie $^{3}$, Rachid Skouta ${ }^{4}$ (D), Abimael H. Vasquez ${ }^{2}$, Cristina Rodríguez-Padilla ${ }^{1}$ (ID \\ and Laura M. Trejo-Avila ${ }^{1, *}$ (iD \\ 1 Laboratorio de Inmunología y Virología, Facultad de Ciencias Biológicas, Universidad Autónoma de Nuevo \\ León, Ciudad Universitaria, CP 66455 San Nicolás de los Garza, NL, Mexico; \\ mario.pena-hernandez@yale.edu (M.A.P.-H.); crrodrig07@gmail.com (C.R.-P.) \\ 2 Department of Chemistry and Biochemistry, Border Biomedical Research Center, The University of Texas at \\ El Paso, El Paso, TX 79968, USA; ahvasquez@miners.utep.edu \\ 3 Programa Maricultura, Facultad de Ciencias Biológicas, Universidad Autónoma de Nuevo León, Ciudad \\ Universitaria, CP 66455 San Nicolás de los Garza, NL, Mexico; lucia.cruzsr@uanl.edu.mx (L.E.C.-S.); \\ denisricque@hotmail.com (D.R.-M.) \\ 4 Department of Biology, University of Massachusetts, Amherst, MA 01003, USA; rskouta@umass.edu \\ * Correspondence: ksmoransant@utep.edu (K.M.-S.); laura.trejoav@uanl.edu.mx (L.M.T.-A.); \\ Tel.: +52-81-83294115 (K.M.-S. \& L.M.T.-A.)
}

Received: 3 August 2018; Accepted: 28 August 2018; Published: 30 August 2018

\begin{abstract}
Although preventable by vaccination, Measles still causes thousands of deaths among young children worldwide. The discovery of new antivirals is a good approach to control new outbreaks that cause such death. In this study, we tested the antiviral activity against Measles virus $(\mathrm{MeV})$ of Polyphenol-rich extracts (PPs) coming from five seaweeds collected and cultivated in Mexico. An MTT assay was performed to determine cytotoxicity effect, and antiviral activity was measured by syncytia reduction assay and confirmed by qPCR. PPs from Ecklonia arborea (formerly Eisenia arborea, Phaeophyceae) and Solieria filiformis (Rhodophyta) showed the highest Selectivity Index (SI), >3750 and $>576.9$ respectively. Both PPs extracts were selected to the subsequent experiments owing to their high efficacy and low cytotoxicity compared with ribavirin (SI of 11.57). The combinational effect of PPs with sulphated polysaccharides (SPs) and ribavirin were calculated by using Compusyn software. Synergistic activity was observed by combining both PPs with low concentrations of Solieria filiformis SPs $(0.01 \mu \mathrm{g} / \mathrm{mL})$. The antiviral activity of the best combinations was confirmed by qPCR. Virucidal assay, time of addition, and viral penetration evaluations suggested that PPs act mainly by inactivating the viral particle. To our knowledge, this is the first report of the virucidal effect of Polyphenol-rich extracts of seaweeds.
\end{abstract}

Keywords: virucidal; Polyphenol-rich extracts; Measles

\section{Introduction}

The discovery of antivirals with high efficacy, low cost, and low cytotoxicity is a long-pursued goal in drug discovery. The marine environment is a wealthy source of biological and chemical diversity of natural antivirals; the investigation of natural antivirals isolated from marine sources is an interesting approach in the development of new antiviral agents [1].

Screening assays of the antiviral activity of extracts from seaweeds have demonstrated the antiviral potency of chemical compounds present in these organisms [2]. Polyphenols are produced by most plants, including seaweeds, where they act as antioxidants that protect from external conditions such 
as stress and herbivores [3]. Some of the compounds found in seaweeds with the best antiviral activity are sulphated polysaccharides and phenolic compounds [4]. The antiviral activity of polyphenols has been observed mainly against enveloped viruses such as Retrovirus, Influenza Virus, Papilloma Virus, Herpes virus, and flaviviruses [5-9]. The Measles virus (MeV) is an enveloped virus that has regained importance as a pathogen as a result of the several recent outbreaks that have occurred in developed countries [10]. Despite the availability of a vaccine, this illness has not been eradicated; hence, the use of an effective antiviral as a therapy could contribute to outbreak containment and lead to eradication.

The strategy of simultaneously attacking multiple targets is a studied approach in the control of viral diseases [11]. Combining targeted therapies have demonstrated multiples advantages in this field, such the reduction of individual drug doses, the decrease in the side effects of antiviral agents, and the prevention of the emergence of drug-resistant viruses [12].

In the present study, we tested the antiviral activity in vitro against $\mathrm{MeV}$ of Polyphenol-rich extracts isolated from five Mexican seaweeds. We tested the combined antiviral effect of the best polyphenols with ribavirin and with sulphated polysaccharides isolated from the same seaweeds with potent antiviral properties [13]. The main goal of this research was to discover new candidates of antiviral drugs with a low cytotoxicity and affordable cost of production that could help control viral infection diseases.

\section{Materials and Methods}

\subsection{Antiviral Agents}

\subsubsection{Collection of Seaweeds}

Five species of Mexican macroalgae were used in this study, three from Baja California (Macrocystis pyrifera, Ecklonia arborea (formerly Eisenia arborea), and Silvetia compressa (formerly Pelvetia compressa), one green seaweed from Southern Baja California (Ulva intestinalis), and one red seaweed from Yucatan (Solieria filiformis). In a previous study, our group reported in detail the collection of these five seaweeds [13].

Macrocystis pyrifera (Linnaeus) C. Agardh was collected in Bahía de Ensenada (Manto Jantay) in front of the Salsipuedes beach $(31.983,-116.815)$, in January 2013. Ecklonia arborea J. E. Areschoug and Silvetia compressa (J. Agardh) De Toni were collected in the Escalera Zone, North of Punta China (31.520, -116.650) in December 2014-January 2015. The green alga Ulva intestinalis (Linnaeus) was collected from the water drainage channel of the Gran Mar shrimp farm, on the Baja California West coast $(24.434,-111.584)$ in August 2014. Solieria filiformis (Kützing) P. W. Gabrielson, was obtained from an aquaculture facility at the Telchac Marine station-CINVESTAV, Yucatan (Mexico), where it is periodically cultivated in bimonthly cycles in semiopen tanks as part of an Integrated Multitrophic aquaculture system. The sample used came from a batch cultured from April to May 2014.

\subsubsection{Polyphenol-Rich Extracts Isolation}

Polyphenol extraction was performed according to Xi et al. [14] with few modifications. Briefly, $10 \mathrm{~g}$ of alga powder was washed with distillated water and dried at room temperature overnight. The washed powder was extracted with $200 \mathrm{~mL} 50 \% v / v$ ethanol and sonicated (Ultrasonic cleaner 50HT, VWR International, West Chester, PA, USA) for $30 \mathrm{~min}$ at room temperature, followed with an extraction period in a bath shaker (Shak-R-bath, Lab-line, Melrose Park, IL, USA) at $70{ }^{\circ} \mathrm{C}$ during $2 \mathrm{~h}$. The samples were centrifuged (IEC Centra MP4R, International equipment company, Needham, MA, USA) for $15 \mathrm{~min}$ (2500 rpm). The supernatant was recovered and added with $96 \%$ ethanol for residual polysaccharides precipitation, before centrifuging for $15 \mathrm{~min}$ ( $2500 \mathrm{rpm}$ ). The ethanol of the supernatant was evaporated at $55^{\circ}$ in a rotary evaporator and the water was eliminated by freeze drying. Dried samples were suspended in Dulbecco's modified Eagle's medium 
(DMEM) (Gibco Invitrogen, Carlsbad, CA, USA) at a concentration of $2.5 \mathrm{mg} / \mathrm{mL}$ and filtered through a membrane filter (pore size, $0.45 \mathrm{~mm}$ ).

\subsection{Cell Line and Virus}

Vero cells (green African monkey kidney cells) were purchased from the American Type Culture Collection (ATCC ${ }^{\circledR}$ CCL-81 ${ }^{\mathrm{TM}}$ ) (Manassas, VA, USA) and were grown at $37^{\circ} \mathrm{C}$ in a $5 \% \mathrm{CO}_{2}$ atmosphere in DMEM/F12 (DMEM/F12, Gibco Invitrogen, Carlsbad, CA, USA) supplemented with 5\% (v/v) fetal bovine serum FBS, Gibco Invitrogen, Carlsbad, CA, USA) and 1\% ( $v / v)$ antibiotic (Gibco Invitrogen, Carlsbad, CA, USA). Measles virus (Edmonston strain) was purchased from ATCC (ATCC ${ }^{\circledR}$ VR-24TM). Virus was propagated on Vero cells and tittered by fifty percent tissue culture infectious dose $\left(\right.$ TCID $\left._{50}\right)$ assay, according to their cytopathic effect (CPE). Aliquots of viral stock were stored at $-80{ }^{\circ} \mathrm{C}$ until use.

\subsection{Cytotoxicity Assay}

The cytotoxicity of the compounds was evaluated by MTT reduction assays. The cells were cultured in 96-well plates at a density of $1.5 \times 10^{4}$ cells/well at $37^{\circ} \mathrm{C}$ in and $5 \% \mathrm{CO}_{2}$. Increasing concentrations of PPs diluted in DMEM (Gibco Invitrogen, Carlsbad, CA, USA) were added; after $48 \mathrm{~h}$ of incubation the media were replaced with MTT solution. After $1 \mathrm{~h} 30 \mathrm{~min} 150 \mu \mathrm{L}$ of DMSO was added to dissolve the formazan crystals and incubated at room temperature for $15 \mathrm{~min}$. The optical density $\left(\mathrm{OD}_{450} \mathrm{~nm}\right.$ ) was measured using a microplate reader (Multiskan FC, Thermo, Waltham, MA, USA). The cytotoxicity was expressed by percentage as the mean value of three independent experiments considering control cells absorbance as $100 \%$ viable. $C_{50}$ was the concentration of the test substances that inhibited the Vero cells growth by $50 \%$ compared with the growth of the untreated cells. All variables were performed in triplicate and repeated at least three times $(\mathrm{N}=9)$.

\subsection{Antiviral Activity}

The antiviral activity of PPs against $\mathrm{MeV}$ was evaluated by syncytia reduction assays. Vero cells seeded in 12-well plates were treated with different concentrations of PPs $(0.01-5 \mu \mathrm{g} / \mathrm{mL})$, and infected with $\mathrm{MeV}\left(1 \times 10^{3.5} \mathrm{TCID}_{50}\right.$ of Edmonston strain $)$ at the same time for $1 \mathrm{~h}$ at $37^{\circ} \mathrm{C}$, allowing the virus to adsorb. After the incubation period, Vero cells were washed with PBS. The assays were performed by adding the compounds during all the infection cycle, i.e., after PBS washing; the compounds were added again and remained until the end of the experiment. Each treatment was tested in triplicate, and each experiment was performed at least in triplicate. After incubation period $\left(48\right.$ or $72 \mathrm{~h}$ at $37^{\circ} \mathrm{C}$ in a $5 \% \mathrm{CO}_{2}$ ) monolayers were fixed with methanol:acetone and stained with $1 \%$ crystal violet in order to observe CPE and count syncyta. The result was expressed as a percentage of total syncytia observed in viral control monolayers (untreated cultures). The $\mathrm{IC}_{50}$ was determined from dose-response curves and the selectivity index (SI) values were calculated as $\mathrm{CC}_{50} / \mathrm{IC}_{50}$. PPs with the best SI were selected for the following experiments. All variables were performed in triplicate and repeated at least three times $(\mathrm{N}=9)$.

\subsection{Quantitative Real-Time PCR}

Total RNA was isolated using RNAzol ${ }^{\circledR}$ RT (MRC Inc., Cincinnati, OH, USA) from treated (1 and $5 \mu \mathrm{g} / \mathrm{mL}$ ) and untreated Vero cells. Reverse transcription was performed using the High Capacity cDNA Reverse Transcription Kit (Applied Biosystems, Foster City, CA, USA) and the viral genome was amplified with specific primers (MeVF: 5' GAGGGTCAAACAGAGTCGAG 3', MeVR: $5^{\prime}$ CGGTTGGAAGATGGGCAG 3'). The real-time PCR was carried out using SensiFASTTM SYBR ${ }^{\circledR}$ No-ROX Kit (BIOLINE, Memphis, TN, USA) and the StepOnePlus Real-Time PCR Systems (Applied Biosystems, Foster City, CA, USA) with the following procedures: $95^{\circ} \mathrm{C}$ for $2 \mathrm{~min}$, followed by 40 cycles of $95^{\circ} \mathrm{C}$ for $2 \mathrm{~s}, 60{ }^{\circ} \mathrm{C}$ for $10 \mathrm{~s}$, and $72{ }^{\circ} \mathrm{C}$ for $20 \mathrm{~s}$. The number of viral copies was calculated using a standard curve (reference) and results were expressed as a percentage of total number of viral 
copies observed in viral control monolayers (untreated cultures). All variables were performed in triplicate and repeated at least three times $(\mathrm{N}=9)$.

\subsection{Evaluation of PPs Synergy}

The combined effect on MeV infection of selected PPs with SPs (with antiviral activity and extracted from the same seaweeds) and ribavirin was evaluated. Each combination was tested on its corresponding $\mathrm{IC}_{25}$ and $\mathrm{IC}_{50}$ using syncytia reduction assays. The synergistic effect of combinations was calculated by using the CompuSyn software which calculates a combination index (CI) described by Chou [15]. As Chou indicated, CI values lower than 0.9 indicate synergism, CI values from 0.9 to 1.1 indicate an additive effect, and CI values higher than 1.1 indicate antagonism. Inhibitory activity of the combinations with the best synergistic effect was confirmed by qPCR assays. All variables were performed in triplicate for each experiment and repeated at least three times $(\mathrm{N}=9)$.

\subsection{Virucidal Assays}

Virucidal activity of PPs against $\mathrm{MeV}$ was determined using syncytia reduction assays with monolayers of Vero cells grown in 12-well plates. The assays where assessed by adding the PPs $(5 \mu \mathrm{g} / \mathrm{mL})$ to an equal volume to $\mathrm{MeV}\left(1 \times 10^{3.5} \mathrm{TCID}_{50}\right.$ of Edmonston strain) After $0,1,3$ and $6 \mathrm{~h}$ of incubation, the mixtures were added to Vero cells and further incubated $1 \mathrm{~h}$ at $37^{\circ} \mathrm{C}$. After that time, the mixtures were removed and media was added. After incubation period $\left(48\right.$ or $72 \mathrm{~h}$ at $37^{\circ} \mathrm{C}$ in a $5 \% \mathrm{CO}_{2}$ ) monolayers were fixed with methanol:acetone and stained with $1 \%$ crystal violet in order to count syncyta. The result was expressed as a percentage of total syncytia observed in viral control monolayers (untreated cultures). All variables were performed in triplicate for each experiment and repeated at least three times $(\mathrm{N}=9)$.

\subsection{Time of Addition Assays}

Vero cell monolayers were infected with $\mathrm{MeV}\left(1 \times 10^{3.5} \mathrm{TCID}_{50}\right.$ of Edmonston strain). PPs $(5 \mu \mathrm{g} / \mathrm{mL})$ were added at different times of infection: $60 \mathrm{~min}$ before infection and $0,15,30$, 60, and $120 \mathrm{~min}$ after infection. Vero cells were incubated with each treatment for $1 \mathrm{~h}$ and then washed three times with PBS. After incubation period of $48 \mathrm{~h}$ at $37^{\circ} \mathrm{C}$ and $5 \% \mathrm{CO}_{2}$ monolayers were fixed with methanol:acetone and stained with $1 \%$ crystal violet; syncytia were counted subsequently and the result was expressed as a percentage of total syncytia observed in viral control monolayers. All variables were performed in triplicate for each experiment and repeated at least three times $(\mathrm{N}=9)$.

\subsection{Viral Penetration Assays}

$\mathrm{MeV}$ penetration into Vero cells was evaluated according to the method reported by Huang and Wagner [16]. Vero cells grown in 12-well plates were precooled at $4{ }^{\circ} \mathrm{C}$ for $3 \mathrm{~h}$ and were infected with $\mathrm{MeV}\left(1 \times 10^{3.5} \mathrm{TCID}_{50}\right.$ of Edmonston strain) at $4{ }^{\circ} \mathrm{C}$ for $1 \mathrm{~h}$ of incubation in the absence of PPs. Thereafter monolayers were washed three times with ice-cold PBS. Different concentrations of PPs $\left(1\right.$ and $5 \mu \mathrm{g} / \mathrm{mL}$ ) were added and the temperature was shifted to $37^{\circ} \mathrm{C}$, then incubated per $1 \mathrm{~h}$ at this temperature. Afterwards, incubation period cells were treated with $40 \mathrm{mM}$ citrate buffer ( $\mathrm{pH}$ 3.0) to inactivate non-penetrated viruses. Thereafter, buffer was replaced by DMEM and monolayers were incubated for $48 \mathrm{~h}$ at $37{ }^{\circ} \mathrm{C}$ and $5 \% \mathrm{CO}_{2}$ and stained with $1 \%$ crystal violet; syncytia were counted subsequently. All variables were performed in triplicate for each experiment, and repeated at least three times $(\mathrm{N}=9)$.

\subsection{Total Phenolic Content (TPC) Evaluation}

The total phenolic content (TPC) was measured using the Folin-Ciocalteu method, which utilizes Gallic acid (GA) as a standard reagent [17]. The Polyphenol-rich extracts were prepared in methanol, with a final concentration of $10 \mathrm{mg} / \mathrm{mL}$. GA stock solution was prepared in methanol to provide 
the standard reference curve according to Skouta et al. [18]. Briefly, $100 \mu \mathrm{L}$ each seaweed extract was transferred into a $1.5 \mathrm{~mL}$ Eppendorf tube and mixed with $200 \mu \mathrm{L}$ of Folin-Ciocalteu reagent (10\%), homogenized for $15 \mathrm{~s}$ (Standard Heavy-Duty Vortex Mixer VWR, Radnor, PA, USA), before adding $800 \mu \mathrm{L}$ of sodium carbonate (700 mM in DI water). The tubes were allowed to stand for $2 \mathrm{~h}$ in complete darkness and $200 \mu \mathrm{L}$ of each sample reaction was transferred to a 96-well microplate and absorbance was registered at $765 \mathrm{~nm}$ in a microplate reader (Epoch 2, BioTek Instruments Inc., Winooski, VT, USA). TPC were determined by comparison of the values obtained with the calibration curve of GA $\left(R^{2}=0.999\right)$. The results were expressed as mg GA equivalents (GAE)/L.

\subsection{High Performance Liquid Chromatography (HPLC) and Mass (MS) Analysis}

The characterization of Polyphenol-rich extracts was carried out using high performance liquid chromatography (HPLC). Samples were suspended in LC-MS metanol and filtered through a membrane filter (pore size, $0.45 \mathrm{~mm}$ ). The separation was achieved on a SunFire (Waters, Milford, MA, USA) C18 $5 \mu \mathrm{m} 4.6 \times 150 \mathrm{~mm}$ column at ambient temperature using a Waters 2487 instrument (Waters, Milford, MA, USA). The mobile phase consisted of acetonitrile with 3\% Acetic Acid (solvent A), water with 3\% Acetic Acid (solvent B). The gradient used to separate Solieria filiformis extract was: $100 \%$ A at $0 \mathrm{~min}, 90 \% \mathrm{~A}$ and $10 \% \mathrm{~B}$ at $3.5 \mathrm{~min}, 50 \% \mathrm{~A}$ and $50 \% \mathrm{~B}$ at $5 \mathrm{~min}$, and $100 \% \mathrm{~B}$ at $10-20 \mathrm{~min}$. To separate Ecklonia arborea extract we used the following gradient: $100 \% \mathrm{~A}$ at $0 \mathrm{~min}, 50 \% \mathrm{~A}$ and $50 \% \mathrm{~B}$ at $2 \mathrm{~min}$, $25 \% \mathrm{~A}$ and $75 \% \mathrm{~B}$ at $5 \mathrm{~min}$, and $100 \% \mathrm{~B}$ at $7-20 \mathrm{~min}$. The flow rate was $1.5 \mathrm{~mL} / \mathrm{min}$ for $20 \mathrm{~min}$ at an injection volume of $10 \mu \mathrm{L}$. Once collected, the fractions were, dried and resuspended in methanol for mass analysis. Liquid chromatography/mass spectra (LC-MS) [+ESI] were taken on a JEOL AccuTOF TC-100 Mass Spectrometer (JEOL Ltd., Tokyo, Japan).

\subsection{Statistical Analysis}

Data were analyzed with SPSS 20 software. All variables were performed in triplicate for each experiment and repeated at least three times $(\mathrm{N}=9) . \mathrm{CC}_{50}$ and $\mathrm{IC}_{50}$ values at $48 \mathrm{~h}$ were determined by Probit regression analysis. One-way ANOVA with Dunnet's post hoc test was used for comparisons vs. viral control. Two-way ANOVA followed by a Tukey analysis were performed when comparing different techniques. The results of were considered significantly different if $p<0.05$.

\section{Results}

\subsection{Cytotoxicity and Antiviral Activity In Vitro of Polyphenol-Rich Extracts of Seaweeds (PPs)}

To determine the cytotoxicity of PPs, an MTT assay was performed. Results indicated no relevant cytotoxicity for any of the PPs tested; $\mathrm{CC}_{50}$ could not be determined for most PPs because of the lack of cytotoxicity at tested concentrations $(0.1$ to $1500 \mu \mathrm{g} / \mathrm{mL})$. On contrary ribavirin exhibited a $\mathrm{CC}_{50}$ of $405 \mu \mathrm{g} / \mathrm{mL}$. Antiviral activity of PPs and ribavirin against $\mathrm{MeV}$ was evaluated by syncytia reduction assays at different concentrations $(0.01,0.1,1$, and $5 \mu \mathrm{g} / \mathrm{mL}$ of each PPs and $10,20,30,40$ and $50 \mu \mathrm{g} / \mathrm{mL}$ of ribavirin). As shown in Table 1 with calculated Selectivity Index values (SI), all tested compounds showed antiviral activity. PPs of Ecklonia (formerly Eisenia) and Solieria showed the best SI values and therefore were selected for the next experiments. As shown in Figure 1, antiviral activity of selected PPs was confirmed by qPCR assays and results were consistent with those observed by Syncytia reduction assays. 
Table 1. Cytotoxic effect, antiviral activity and selectivity index of PPs.

\begin{tabular}{cccc}
\hline Extract or Compound $^{\mathbf{a}}$ & $\mathbf{C C}_{\mathbf{5 0}}(\boldsymbol{\mu g} / \mathbf{m L})^{\mathbf{b}}$ & $\mathbf{I C}_{\mathbf{5 0}}(\boldsymbol{\mu g} / \mathbf{m L})^{\mathbf{c}}$ & $\mathbf{S I}^{\mathbf{d}}$ \\
\hline Macrocystis pyrifera (Phaeophyceae) PP & $>1500$ & $3 \pm 0.33$ & $>500$ \\
Ecklonia arborea (formerly Eisenia arborea, Phaeophyceae) PP & $>1500$ & $2.6 \pm 0.28$ & $>576.9$ \\
Silvetia compressa (formerly Pelvetia compressa, Phaeophyceae) PP & $165.03 \pm 9.7$ & $1.86 \pm 0.61$ & 306.9 \\
Ulva intestinalis (Chlorophyta) PP & $>1500$ & $3.1 \pm 0.23$ & $>483.9$ \\
Solieria filiformis (Rhodophyta) PP & $>1500$ & $0.4 \pm 0.11$ & $>3750$ \\
Ribavirin & $405 \pm 4.1$ & $35 \pm 1.8$ & 11.57 \\
\hline
\end{tabular}

${ }^{\mathbf{a}}$ Polyphenol-rich extracts of seaweeds or compound. ${ }^{\mathbf{b}}$ Concentration of test compound $(\mu \mathrm{g} / \mathrm{mL})$ that reduced Vero cell viability by $50 \% .{ }^{\mathbf{c}}$ Concentration of a test compound that reduced the number of $\mathrm{MeV}$ syncytia in Vero cells by $50 \%{ }^{\text {d }}$ Selectivity index value.

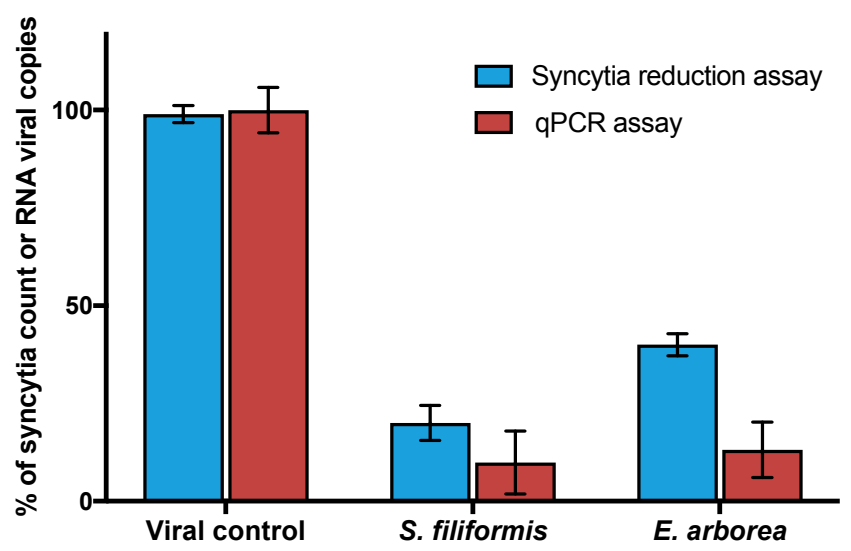

Figure 1. Antiviral activity of Ecklonia arborea and Solieria filiformis extracts. PPs were tested at $5 \mu \mathrm{g} / \mathrm{mL}$ by syncytia reduction and qPCR assays. Syncytia count and viral RNA copies number are given in \% of the untreated control values. Each bar represents the average of three replicates.

\subsection{Combined Effect of Polyphenol-Rich Extracts (PPs) with Sulphated Polysaccharides (Sps) and Ribavirin}

The antiviral effect of PPs in combination with SPs (with antiviral activity tested and extracted of the same seaweeds) [13] and ribavirin was assessed by syncytia-reduction assays. Inhibitory concentrations $50 \%$ and $25 \%\left(\mathrm{IC}_{50}\right.$ and $\left.\mathrm{IC}_{25}\right)$ of PPs were tested with their corresponding $\mathrm{IC}_{50}$ and $\mathrm{IC}_{25}$ of SPs and ribavirin. Combinational Index values of all combinations were calculated using the CompuSyn software [15]. Combined effect of PPs and SPs is given in Table 2, where 10 of the 16 combinations showed synergism. Combinations of PPs from Ecklonia arborea (formerly Eisenia) as well as PPs from Solieria filiformis with SPs from Solieria filiformis showed the best synergistic effects and were confirmed by qPCR (Figure 2). IC $\mathrm{I}_{50}$ of Ecklonia arborea (formerly Eisenia) PPs and $\mathrm{IC}_{25}$ of Solieria filiformis SPS combination ( $\mathrm{PPE}_{50} / \mathrm{SPS}_{25}$ ) showed the best synergistic effect. By contrast, Table 3 indicates the combined effect of PPs with ribavirin, as shown in the table; all the tested combinations were antagonic. 
Table 2. Combined antiviral effect of PPs and SPs of Ecklonia arborea and Solieria filiformis.

\begin{tabular}{|c|c|c|c|c|c|c|c|c|}
\hline \multirow{2}{*}{ Combination } & \multicolumn{4}{|c|}{ Compound Concentration $(\mu \mathrm{g} / \mathrm{mL})$} & \multirow{2}{*}{$\begin{array}{c}\% \text { Relative } \\
\text { Syncytia of Each } \\
\text { Combination }\end{array}$} & \multirow{2}{*}{ SD } & \multirow{2}{*}{ CI } & \multirow{2}{*}{ Description } \\
\hline & $\begin{array}{c}\text { Ecklonia } \\
\text { arborea }\end{array}$ & $\begin{array}{c}\text { Solieria } \\
\text { filiformis }\end{array}$ & $\begin{array}{c}\text { Ecklonia } \\
\text { arborea }\end{array}$ & $\begin{array}{c}\text { Solieria } \\
\text { filiformis }\end{array}$ & & & & \\
\hline $\mathrm{PPE}_{50}-\mathrm{SPE}_{50}$ & 2.6 & - & 0.275 & - & 38.8 & 3.5 & 0.79 & Synergism \\
\hline $\mathrm{PPE}_{25}-\mathrm{SPE}_{50}$ & 0.03 & - & 0.275 & - & 49.1 & 6.8 & 1.75 & Antagonism \\
\hline $\mathrm{PPS}_{50}-\mathrm{SPE}_{50}$ & - & 0.4 & 0.275 & - & 55.1 & 8.1 & 4.4 & Antagonism \\
\hline $\mathrm{PPE}_{25} / \mathrm{SPE}_{25}$ & 0.03 & - & 0.01 & - & 73.5 & 2.6 & 3.6 & Antagonism \\
\hline $\mathrm{PPS}_{50} / \mathrm{SPE}_{25}$ & - & 0.4 & 0.01 & - & 44.9 & 3.3 & 0.4 & Synergism \\
\hline $\mathrm{PPS}_{25} / \mathrm{SPE}_{25}$ & - & 0.07 & 0.01 & - & 57.14 & 6.7 & 0.4 & Synergism \\
\hline $\mathrm{PPE}_{50} / \mathrm{SPS}_{50}$ & 2.6 & - & - & 0.985 & 22.5 & 6.2 & 0.57 & Synergism \\
\hline $\mathrm{PPE}_{25} / \mathrm{SPS}_{50}$ & 0.03 & - & - & 0.985 & 34.5 & 8.3 & 1.85 & Antagonism \\
\hline $\mathrm{PPS}_{50} / \mathrm{SPS}_{25}$ & - & 0.4 & - & 0.01 & 33.3 & 1.8 & 0.03 & Synergism \\
\hline $\mathrm{PPS}_{25} / \mathrm{SPS}_{25}$ & - & 0.07 & - & 0.01 & 38.8 & 2.5 & 0.11 & Synergism \\
\hline
\end{tabular}

* PPE and PPS correspond to polyphenol-rich extract of Ecklonia arborea and Solieria filiformis respectively; *SPE and SPS correspond to polysaccharides of Ecklonia arborea and Solieria filiformis respectively.

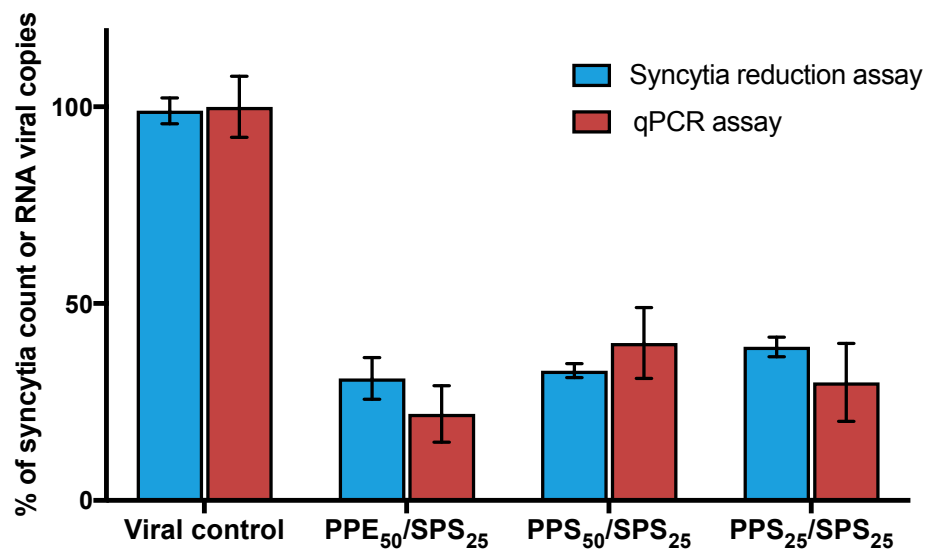

Figure 2. Antiviral activity of synergistic combinations of PPs and SPs. PPs and SPs were combined with their $\mathrm{IC}_{25 \%}$ and $\mathrm{IC}_{50 \%}$ and the antiviral effect was determined by syncytia reduction and qPCR assays. Syncytia count and viral RNA copies number are given in $\%$ of the untreated control values. Each bar represents the average of three replicates.

Table 3. Combined antiviral effect of PPs of Ecklonia arborea and Solieria filiformis with ribavirin.

\begin{tabular}{|c|c|c|c|c|c|c|c|}
\hline \multirow{3}{*}{ Combination } & \multicolumn{3}{|c|}{ Concentration $(\mu \mathrm{g} / \mathrm{mL})$} & \multirow{3}{*}{$\begin{array}{c}\text { \% Relative } \\
\text { Syncytia of Each } \\
\text { Combination }\end{array}$} & \multirow{3}{*}{ SD } & \multirow{3}{*}{ CI } & \multirow{3}{*}{ Description } \\
\hline & \multicolumn{2}{|c|}{ Polyphenols PPE or PPS * } & \multirow[b]{2}{*}{ Ribavirin } & & & & \\
\hline & $\begin{array}{c}\text { Ecklonia } \\
\text { arborea }\end{array}$ & $\begin{array}{c}\text { Solieria } \\
\text { filiformis }\end{array}$ & & & & & \\
\hline $\mathrm{PPE}_{50} / \mathrm{R}_{50}$ & 2.6 & - & 35 & 4 & 0.5 & 9.1 & Antagonism \\
\hline $\mathrm{PPE}_{50} / \mathrm{R}_{25}$ & 2.6 & - & 16 & 32 & 1.1 & 2.6 & Antagonism \\
\hline $\mathrm{PPE}_{25} / \mathrm{R}_{50}$ & 0.03 & - & 35 & 20 & 1.8 & 1.3 & Antagonism \\
\hline $\mathrm{PPE}_{25} / \mathrm{R}_{25}$ & 0.03 & - & 16 & 33.2 & 1.5 & 1.2 & Antagonism \\
\hline $\mathrm{PPS}_{50} / \mathrm{R}_{50}$ & - & 0.4 & 35 & 13.6 & 1.2 & 3.6 & Antagonism \\
\hline $\mathrm{PPS}_{50} / \mathrm{R}_{25}$ & - & 0.4 & 16 & 36.4 & 1.9 & 2.5 & Antagonism \\
\hline $\mathrm{PPS}_{25} / \mathrm{R}_{50}$ & - & 0.07 & 35 & 24.3 & 2.1 & 2.2 & Antagonism \\
\hline $\mathrm{PPS}_{25} / \mathrm{R}_{25}$ & - & 0.07 & 16 & 30.3 & 1.8 & 1.3 & Antagonism \\
\hline
\end{tabular}

${ }^{*}$ PPE and PPS correspond to polyphenol-rich extract of Ecklonia arborea and Solieria filiformis respectively. 


\subsection{Virucidal Activity of Polyphenol-Rich Extracts (PPs)}

A virucidal assay was performed to analyze if the compounds act directly on the virus particle leading to infectivity inactivation. Virucidal activity was tested at $5 \mu \mathrm{g} / \mathrm{mL}$ in both PPs. Results determined that inhibitory activity increases directly proportional to the time of between the extracts and virus (Figure 3). Inhibitory activity observed at $6 \mathrm{~h}$ leads to $83-89 \%$ of inhibition. Therefore, both PPs (Ecklonia arborea and Solieria filiformis) have a potential virucidal activity by inactivating viral particles.

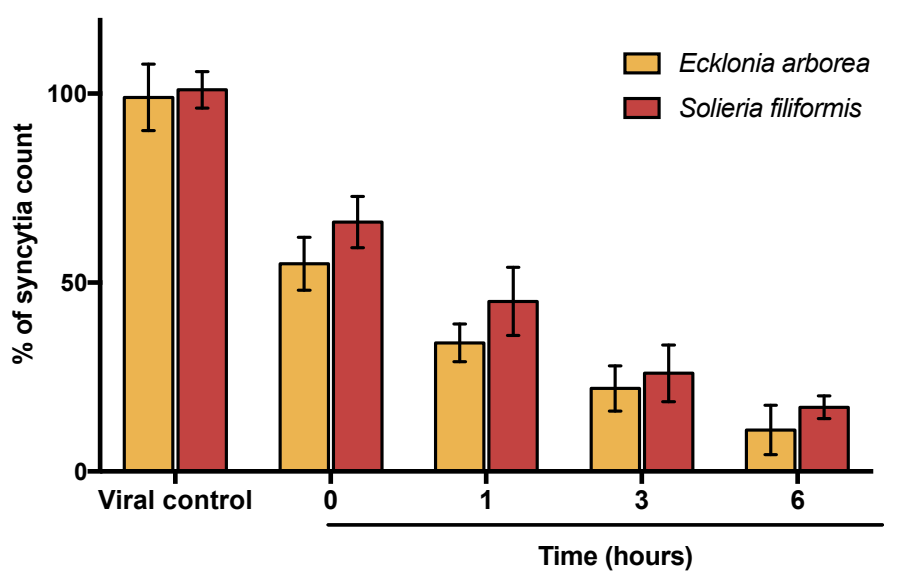

Figure 3. Virucidal effect of PPs. Vero cells were infected with $\mathrm{MeV}$ previously exposed to PPs at different times $(0,1,3$ and $6 \mathrm{~h})$. Syncytia count is given in $\%$ of the untreated control values. Each bar represents the average of three replicates.

\subsection{Effect of Polyphenol-Rich Extracts (PPs) at Different Times of Addition}

Time of addition experiments were performed to determine which step of the MeV cycle was targeted by PPs. Vero cells were infected with $\mathrm{MeV}$ and compounds were added at different times (60 min before infection and 0, 15, 30, 60, and 120 min after infection). As shown in Figure 4, results determined PPs from Ecklonia arborea, as well as PPS from Solieria filiformis, have their best antiviral activity at the first minutes of infection (0-15 $\mathrm{min})$. Inhibitory activity observed at different times was lower than the observed in virucidal assays $(6 \mathrm{~h})$. The activity in the first minutes of infection suggests that inhibitory activity of PPs is possible due to a direct inactivation of the viral particle.

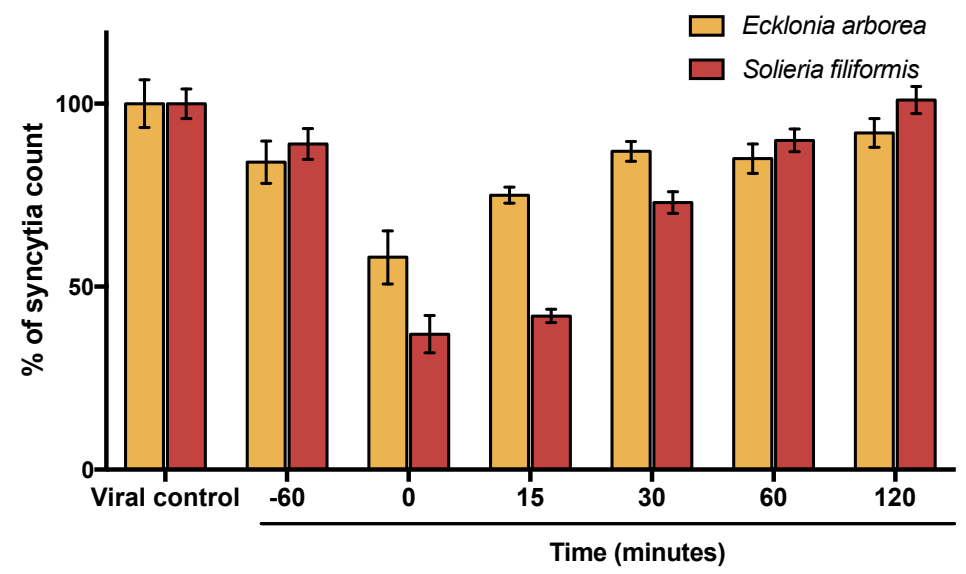

Figure 4. Time of addition assay. Antiviral activity of PPs was tested at different times of infection and analyzed by syncytia reduction assays. PPs were added to the cells $60 \mathrm{~min}$ before infection and at 0,15 , 30,60 , and $120 \mathrm{~min}$ after infection. Syncytia count is given in \% of the untreated control values. Each bar represents the average of three replicates. 


\subsection{Effect of Polyphenol-Rich Extracts (PPs) in Viral Entry}

A viral entry assay was performed to determine whether entry events, downstream of virus binding, were inhibited by PPs. Monolayers were incubated with $\mathrm{MeV}$ at $4{ }^{\circ} \mathrm{C}$ for $1 \mathrm{~h}$ to allow virus binding but no viral entry. The unbound virus was inactivated with citrate buffer, and PPs $(1 \mu \mathrm{g} / \mathrm{mL}$ or $5 \mu \mathrm{g} / \mathrm{mL}$ ) were added to the cells and incubated at $37^{\circ} \mathrm{C}$ in a $5 \% \mathrm{CO}_{2}$. As shown in Figure 5, the best inhibitory effect was observed with $S$. filiformis PPs $(5 \mu \mathrm{g} / \mathrm{mL})$, compared with the results in untreated cells.

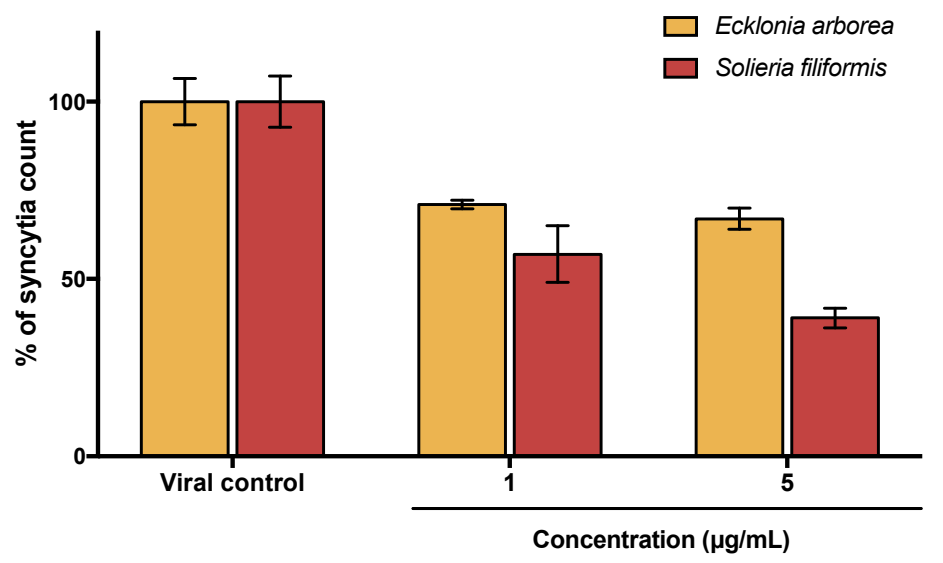

Figure 5. Effect of PPs on viral penetration. Vero cells were infected with $\mathrm{MeV}$ at $4{ }^{\circ} \mathrm{C}$ in the absence of PPs and then shifted to $37^{\circ} \mathrm{C}$ to permit penetration of the adsorbed virus in the presence of PPs. Syncytia count is given in \% of the untreated control values. Each bar represents the average of three replicates.

\subsection{Estimated Total Phenolic Content (TPC)}

The Folin-Ciocalteu method was used to determine total phenolic content of Ecklonia arborea and Solieria filiformis PPs. The TPC of each extract was determined using a regression equation of the calibration curve and expressed as gallic acid equivalents (GAE). Estimated TPC of Ecklonia arborea and Solieria filiformis were $179.16 \pm 11.38$ (GAE)/L and 102.22 \pm 15.10 (GAE)/L respectively.

\subsection{Polyphenol-Rich Extracts (PPs) Characterization by High Performance Liquid Chromatography (HPLC)} and Mass (MS) Analysis

After optimizing HPLC conditions, we identified and collected six potential fractions in Solieria filiformis PPs (Figure 6A) and five fractions in Ecklonia arborea PPs (Figure 6B). Once collected, fractions were submitted to mass analysis. To identify tentative compounds in each isolated fraction based on mass spectra, we used the European MassBank, Phenol-Explores 3.6, and MassBank of North America databases [19-21]. The potential identification of each fraction from Polyphenol-rich extracts is shown in Tables 4 and 5.

A)

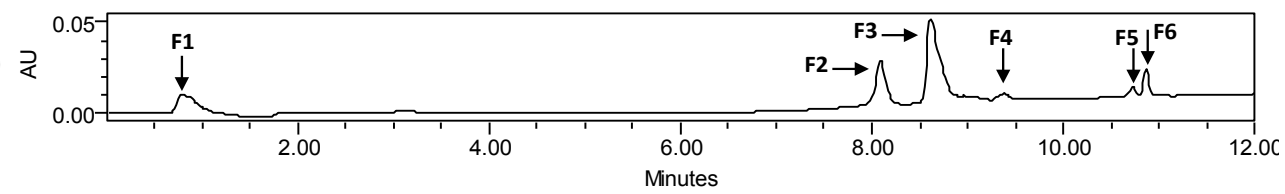

B)

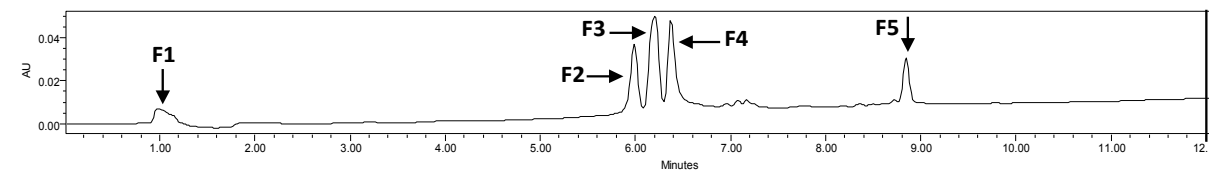

Figure 6. Chromatograms obtained for: (A) Solieria filiformis PPs; (B) Ecklonia arborea PPs, detection at $270 \mathrm{~nm}$. The fractions collected are numbered (F1-F6) as indicated. 
Table 4. HPLC Fractions of Polyphenol-rich extract isolated from Solieria filiformis.

\begin{tabular}{|c|c|c|c|}
\hline Fraction & Retention Time (min) & $\begin{array}{l}\text { Major Fragment Ions } m / z \\
\text { (\% Base Peak) }\end{array}$ & Tentative Identification \\
\hline $\mathrm{F} 1$ & 0.802 & $\begin{array}{c}298.339(100), 136.989(92.09), \\
150.115(91.36)\end{array}$ & $\begin{array}{l}\text { 5-Methylthioadenosine }{ }^{\mathrm{a}, \mathrm{b}} \\
\text { Inosine }^{\mathrm{a}, \mathrm{b}}, \mathrm{L}-\text {-Methionine } \\
\mathrm{a}\end{array}$ \\
\hline F2 & 8.109 & $230.243(100)$ & Terbutylazine $^{\mathrm{a}, \mathrm{b}}$ \\
\hline F3 & 8.620 & $\begin{array}{c}507.299(100), 683.430(98.13) \\
639.405(97.21), 551.349 \\
(95.74), 595.376(91.57)\end{array}$ & $\begin{array}{l}\text { Quercetin 3-(6-O-acetyl-beta-glucoside) }{ }^{\mathrm{a}, \mathrm{b}} \text {, } \\
\text { Methyllycaconitine }{ }^{\mathrm{a}, \mathrm{b}} \text {, Demethoxycentaureidin } \\
\text { 7-O-rutinoside }{ }^{\mathrm{ab}} \text {, Quercetin } \\
\text { 3-O-(6 (6 -malonyl-glucoside) }{ }^{\mathrm{a}, \mathrm{b}, \mathrm{c}}, \\
\text { Kaempferol-3-O-rutinoside } \\
\text { a,b,c. }\end{array}$ \\
\hline F4 & 9.382 & $301.134(100)$ & Kaempferide $^{\mathrm{a}}$ \\
\hline F5 & 10.716 & 413. $256(100)$ & $\begin{array}{l}\text { 7-acetyloxy-2-(3,4-diacetyloxyphenyl)-4- } \\
\text { oxochromen-5-yl acetate }^{\text {a }}\end{array}$ \\
\hline F6 & 10.860 & $264.237(100)$ & Abscisic acid ${ }^{\mathrm{a}, \mathrm{b}}$ \\
\hline
\end{tabular}

Table 5. HPLC Fractions of Polyphenol-rich extract isolated from Ecklonia arborea.

\begin{tabular}{|c|c|c|c|}
\hline Fraction & Retention Time (min) & $\begin{array}{c}\text { Major Fragment Ions } \mathrm{m} / \mathrm{z} \\
\text { (\% Base Peak) }\end{array}$ & Tentative Identification \\
\hline $\mathrm{F} 1$ & 1.052 & $\begin{array}{l}\text { 365. 125(100), } 205.064(98.23) \\
601.138(40)\end{array}$ & $\begin{array}{l}\text { Cellobiose }^{\mathrm{a}, \mathrm{b}}, \text { Tryptophan }^{\mathrm{a}} \\
\text { Phlorofucofuroeckol-B }^{\mathrm{c}}\end{array}$ \\
\hline F2 & 5.982 & $\begin{array}{c}602.140(100), 268.993(73.23) \\
230.244(68.75)\end{array}$ & $\begin{array}{c}\text { Phlorofucofuroeckol-B }{ }^{\mathrm{c}}, \text { Formononetin }^{\mathrm{a}, \mathrm{b}} \\
\text { Apigenin } 7-\mathrm{O} \text {-glucoside }\end{array}$ \\
\hline F3 & 6.195 & $413.259(100), 327.195$ (67.57) & $\begin{array}{l}\text { Leganin }^{\mathrm{a}} \\
\text { Feruloyl tartaric acid }^{\mathrm{a}}\end{array}$ \\
\hline F4 & 6.733 & $205.074(100)$ & Tryptophan $^{\text {a }}$ \\
\hline F5 & 8.844 & $601.139(100)$ & Phlorofucofuroeckol-B $^{\mathrm{c}}$ \\
\hline
\end{tabular}

${ }^{\text {a }}$ Confirmed with Mass Spectroscopy (MS) fragmentation and European MassBank results; ${ }^{b}$ Confirmed with Mass Spectroscopy (MS) fragmentation and Phenol-Explores 3.6 results; ${ }^{\mathrm{c}}$ Confirmed based on Choi et al. [22].

\section{Discussion}

The research of biological activities of marine products has yielded many bioactive compounds showing various pharmaceutical properties [23]. The demand for new antiviral agent discovery against emergent and re-emergent viruses has grown due to recent outbreaks. For this reason, the aim of the present study was to evaluate the antiviral activity of Polyphenol-rich extracts isolated from Mexican seaweeds against Measles virus.

One of the major challenges in the development of new antivirals is to find a compound with no cytotoxicity. Most of the Polyphenol-rich extracts tested in this study did not demonstrate cytotoxicity activity in Vero cells at high concentrations (Table 1). The lack of cytotoxicity of PPs isolated from seaweeds in Vero cells was also reported by Namvar et al., through testing of phlorotanins extracted from Sargassum muticum (Phaeophyceae) at concentrations lower than $200 \mu \mathrm{g} / \mathrm{mL}$ [24].

The use of secondary metabolites of algae as antiviral agents has been tested for a large number of enveloped viruses of medical and veterinary importance [25-28]. Seaweeds sulphated polysaccharides have also been extensively studied for antiviral activity, but seaweeds polyphenols are relatively new to antiviral research [29-31]. All of the PPs evaluated showed antiviral activity against MeV (Table 1). Polyphenol-rich extracts of Solieria filiformis and Ecklonia arborea (formerly Eisenia arborea) showed the highest Selectivity Index ( $>3750$ and $>576.9$ respectively) and were selected to the subsequent experiments due to their high efficacy and low cytotoxicity by comparing with ribavirin, an FDA 
approved antiviral (SI of 11.57). Syncytia formation and viral titration by qPCR were used to evaluate antiviral activity of both extracts (Figure 1). A significant reduction between controls and treatments was observed with both techniques, but substantial significance differences were observed by comparing the highest concentrations tested of PPs in both techniques. Although PCR is typically a more sensitive method than tissue culture techniques, the presence of viral RNA may not always reflect an association with infective viruses production [32].

Synergistic activity of secondary metabolites of seaweeds has been reported for our group. We previously tested the combinational activity of sulfated polysaccharides (SPs) isolated from the same five seaweeds and observed a synergistic effect because of the different mode of action in the SPs evaluated [13]. In this study, we tested the antiviral activity of PPs in combination with SPs extracted of the same seaweeds and ribavirin. The combinations with the best synergistic activity were observed by combining PPs of Solieria filiformis as well as Ecklonia arborea PPs with SPs of Solieria filiformis at low concentrations $(0.01 \mu \mathrm{g} / \mathrm{mL})$ (Table 2$)$. The antiviral activity of the best combinations was confirmed by qPCR (Figure 2). All of the evaluated combinations of PPs with ribavirin showed an antagonic effect (Tale 3). Owing to the synergistic effect observed by combining PPs and SPs, we questioned the different mode of action between both extracts; therefore, we assayed three different techniques to elucidate the mode of action of PPs. The virucidal activity of PPs of Solieria filiformis and Ecklonia arborea was tested in order to determine if the compounds are inactivating the virus before the infection of Vero cells (Figure 3). Both polyphenols were shown to have a remarkable inhibitory effect at minute 0 and 15 of the infection (Figure 4); a decrease in syncytia and viral load was found in the viral penetration tests (Figure 5); the best inhibitory effect was observed when performing the virucidal test, decreasing to $90 \%$ the formation of syncytia after $6 \mathrm{~h}$ of PPs-virus interaction (Figure 3). It is possible that the effect of these Polyphenol-rich extracts is the direct deactivation of the virion, which therefore, prevents it from adsorbing and penetrating the host cell, an effect that we consistently see in the addition and penetration times tests. Virucidal activity of polyphenols has been observed previously, such as, polyphenols isolated from Cistus (Tracheophyta, Magnoliopsida), a floral plant that showed virucidal effect against Influenza virus through inhibition of HA binding to cellular receptors [33].

The total phenolic content test confirmed that both extracts are rich in phenolic compounds. HPLC and mass analysis allowed us to identify potential natural compounds that may be playing an important role in the antiviral activity of the extract. Six fractions and five fractions were collected from Solieria filiformis and Ecklonia arborea extracts, respectively (Figure 6A,B). Tentative compounds identified in Solieria filiformis extract are mostly phenolic compounds previously reported as secondary metabolites of seaweeds (Table 4). Quercetin and kaempherol were reported in high percentages in the red seaweed Gracilaria dendroides (Rhodophyta), which showed antimicrobial activity [34]. High concentrations of quercetin were found in a polyphenol-rich extract isolated from the red seaweed Kappaphycus alvarezii (formerly Eucheuma cottonii) which suppressed breast tumor via hormone modulation and apoptosis induction [35]. Antiviral activity of quercetin and kaempherol has been reported against Herpes Simplex Virus and Influenza virus, as well as the synergistic antiviral effect [36,37]. Phlorofucofuroeckol-B, a compound identified in the Ecklonia arborea (formerly Eisenia arborea) extract, is a phlorotannin previously reported in this brown seaweed (Table 5). Phlorofucofuroeckol-B, isolated from Ecklonia bicyclis (formerly Eisenia bicilys) and Ecklonia arborea, has also been reported as showing potent antioxidant and anti-allergic [38,39]. Antiviral activity in vitro of phlorofucofuroeckol-A isolated from Ecklonia bicilys (formerly Eisenia bicilys) against murine norovirus was reported to have a Selectivity index of 668.87 [31]. Even though there are some reports about the antiviral activity of seaweeds polyphenols that prevent viral adsorption and replication [40], this is the first report of the virucidal effect of Polyphenol-rich extracts of seaweeds, to our knowledge.

\section{Conclusions}

In summary, our study demonstrates that Polyphenol-rich extracts isolated from Mexican seaweeds have significant virucidal activities against Measles virus in vitro. Virucidal activity of 
the extract is not only a prophylactic strategy before viral infection, but can also be successful as a treatment after infection, avoiding virus dissemination. The synergistic effect shown with sulphated polysaccharides proposed a desirable therapeutic effect, reducing the concentration of the compounds, thereby also their cellular toxicity, and avoiding the resistance of the virus to the action of these compounds.

Author Contributions: Conceptualization: K.M.-S., L.M.T.-A. and L.E.C.-S.; Methodology: K.M.-S., M.A.P.-H. and A.H.V.; Software: K.M.-S., M.A.P.-H., A.H.V. and D.R.-M.; Validation: M.A.P.-H. and R.S.; Formal Analysis: K.M.-S., L.M.T.-A. and L.E.C.-S.; Investigation: K.M.-S., M.A.P.-H. and A.H.V.; Resources: L.E.C.-S., D.R.-M., R.S. and C.R.-P.; Data Curation: K.M.-S., L.M.T.-A., R.S. and L.E.C.-S.; Writing-Original Draft Preparation: K.M.-S., M.A.P.-H., L.M.T.-A.; Writing-Review \& Editing, L.E.C.-S., D.R.-M.; Visualization, K.M.-S., M.A.P.-H., A.H.V.; Supervision, L.M.T.-A., L.E.C.-S., C.R.-P.; Project Administration, L.M.T.-A., C.R.-P.; Funding Acquisition, L.M.T.-A., L.E.C.-S.

Funding: This research was funded by Consejo Nacional de Ciencia y Tecnología (CONACYT), México (Project no. 10002-0215075). K.M.-S. was supported by CONACYT and ConTex program. The RISE Scholars Program at UTEP through Grant No R25GM069621-11 supported A.H.V.

Acknowledgments: The authors would like to thank: Laboratorio de Inmunlogía y Virología for the use of the facilities, the Border Biomedical Research Center-UTEP (NIMHD/G12MD007592) for the use of the shared equipment, D. Robledo for provide S. filiformis seaweed material and M. Maldonado for PPs extraction support.

Conflicts of Interest: The authors declare no conflict of interest.

\section{References}

1. Van Minh, C.; Van Kiem, P.; Hai Dang, N. Marine natural products and their potential application in the future. ASEAN J. Sci. Technol. Dev. 2005, 22, 297-311. [CrossRef]

2. Gheda, S.F.; El-Adawi, H.I.; El-Deeb, N.M. Antiviral profile of brown and red seaweed polysaccharides against Hepatitis C Virus. Iran J. Pharm. Res. 2016, 15, 483-491. [PubMed]

3. Chojnacka, K.; Saeid, A.; Witkowska, Z.; Tuhy, Ł. Biologically active compounds in seaweed extractsThe prospects for the application. Open Conf. Proc. J. 2012, 3, 20-28. [CrossRef]

4. Pérez, M.J.; Falqué, E.; Domínguez, H. Antimicrobial action of compounds from marine seaweed. Mar. Drugs 2016, 14, 52. [CrossRef] [PubMed]

5. Zhang, X.; Xia, Q.; Yang, G.; Zhu, D.; Shao, Y.; Zhang, J.; Cui, Y.; Wang, R.; Zhang, L. The anti-HIV-1 activity of polyphenols from Phyllanthus urinaria and the pharmacokinetics and tissue distribution of its marker compound, gallic acid. J. Tradit. Chin. Med. Sci. 2017, 4, 158-166. [CrossRef]

6. Yang, Z.F.; Bai, L.P.; Huang, W.B.; Li, X.Z.; Zhao, S.S.; Zhong, N.S.; Jiang, Z.H. Comparison of in vitro antiviral activity of tea polyphenols against influenza $A$ and $B$ viruses and structure-activity relationship analysis. Fitoterapia 2014, 93, 47-53. [CrossRef] [PubMed]

7. Stockfleth, E.; Meyer, T. The use of sinecatechins (polyphenon E) ointment for treatment of external genital warts. Expert Opin. Biol. Ther. 2012, 12, 783-793. [CrossRef] [PubMed]

8. Vázquez-Calvo, A.; de Oya, N.J.; Martín-Acebes, M.A.; Garcia-Moruno, E.; Saiz, J.C. Antiviral properties of the natural polyphenols delphinidin and epigallocatechin gallate against the flaviviruses West Nile Virus, Zika Virus, and Dengue Virus. Front. Microbiol. 2017, 8, 1314. [CrossRef] [PubMed]

9. Date, A.A.; Destache, C.J. Natural polyphenols: Potential in the prevention of sexually transmitted viral infections. Drug Discov. Today 2016, 21, 333-341. [CrossRef] [PubMed]

10. Orenstein, W.A.; Cairns, L.; Hinman, A.; Nkowane, B.; Olivé, J.M.; Reingold, A.L. Measles and Rubella Global Strategic Plan 2012-2020 midterm review report: Background and summary. Vaccine 2018, 36, A35-A42. [CrossRef] [PubMed]

11. Teeraananchai, S.; Kerr, S.J.; Amin, J.; Ruxrungtham, K.; Law, M.G. Life expectancy of HIV-positive people after starting combination antiretroviral therapy: A meta-analysis. HIV Med. 2017, 18, 256-266. [CrossRef] [PubMed]

12. Pires de Mello, C.P.; Drusano, G.L.; Adams, J.R.; Shudt, M.; Kulawy, R.; Brown, A.N. Oseltamivir-zanamivir combination therapy suppresses drug-resistant H1N1 influenza A viruses in the hollow fiber infection model (HFIM) system. Eur. J. Pharm. Sci. 2018, 111, 443-449. [CrossRef] [PubMed] 
13. Morán-Santibañez, K.; Cruz-Suárez, L.E.; Ricque-Marie, D.; Robledo, D.; Freile-Pelegrín, Y.; Peña-Hernández, M.A.; Rodríguez-Padilla, C.; Trejo-Avila, L.M. Synergistic effects of sulfated polysaccharides from Mexican seaweeds against Measles virus. BioMed Res. Int. 2016, 2016, 8502123. [CrossRef] [PubMed]

14. Xi, J.; Shen, D.; Zhao, S.; Lu, B.; Li, Y.; Zhang, R. Characterization of polyphenols from green tea leaves using a high hydrostatic pressure extraction. Int. J. Pharm. 2009, 382, 139-143. [CrossRef] [PubMed]

15. Chou, T.C. Drug combination studies and their synergy quantification using the Chou-Talalay method. Cancer Res. 2010, 70, 440-446. [CrossRef] [PubMed]

16. Huang, A.S.; Wagner, R.R. Penetration of Herpes Simplex Virus into Human Epidermoid Cells. Exp. Biol. Med. 1964, 116, 863-868. [CrossRef]

17. Ainsworth, E.A.; Gillespie, K.M. Estimation of total phenolic content and other oxidation substrates in plant tissues using Folin-Ciocalteu reagent. Nat. Protoc. 2007, 2, 875-877. [CrossRef] [PubMed]

18. Skouta, R.; Morán-Santibañez, K.; Valenzuela, C.A.; Vasquez, A.H.; Fenelon, K. Assessing the Antioxidant Properties of Larrea tridentata Extract as a Potential Molecular Therapy against Oxidative Stress. Molecules 2018, 23, 1826. [CrossRef] [PubMed]

19. Horai, H.; Arita, M.; Kanaya, S.; Nihei, Y.; Ikeda, T.; Suwa, K.; Ojima, Y.; Tanaka, K.; Tanaka, S.; Aoshima, K.; et al. MassBank: A public repository for sharing mass spectral data for life sciences. J. Mass Spectrom. 2010, 45, 703-714. [CrossRef] [PubMed]

20. Neveu, V.; Perez-Jiménez, J.; Vos, F.; Crespy, V.; Chaffaut, L.; Mennen, L.; Knox, C.; Neveu, V.; Eisner, R.; Cruz, J.; et al. Phenol-Explorer: An online comprehensive database on polyphenol contents in foods. Database 2010, 2010, bap024. [CrossRef] [PubMed]

21. MassBank of North America. Available online: http:/ / mona.fiehnlab.ucdavis.edu/ (accessed on 27 July 2018).

22. Choi, J.-S.; Lee, K.; Lee, B.-B.; Kim, Y.-C.; Kim, Y.D.; Hong, Y.-K.; Cho, K.K.; Choi, I.S. Antibacterial activity of the phlorotannins dieckol and phlorofucofuroeckol-A from Ecklonia cava against Propionibacterium acnes. Bot. Sci. 2014, 92, 425-431. [CrossRef]

23. Karadeniz, F.; Karagozlu, M.Z.; Kim, S. Antiviral Activities of Marine Algal Extracts. In Marine Algae Extracts; Wiley-VCH: Weinheim, Germany, 2015; pp. 371-380.

24. Namvar, F.; Mohamad, R.; Baharara, J.; Zafar-Balanejad, S.; Fargahi, F.; Rahman, H.S. Antioxidant, Antiproliferative, and Antiangiogenesis Effects of Polyphenol-Rich Seaweed (Sargassum muticum). BioMed Res. Int. 2013, 2013, 604787. [CrossRef] [PubMed]

25. Elizondo-Gonzalez, R.; Cruz-Suarez, L.E.; Ricque-Marie, D.; Mendoza-Gamboa, E.; Rodriguez-Padilla, C.; Trejo-Avila, L.M. In vitro characterization of the antiviral activity of fucoidan from Cladosiphon okamuranus against Newcastle Disease Virus. Virol. J. 2012, 9, 307. [CrossRef] [PubMed]

26. Aguilar-Briseño, J.A.; Cruz-Suarez, L.E.; Sassi, J.F.; Ricque-Marie, D.; Zapata-Benavides, P.; Mendoza-Gamboa, E.; Rodríguez-Padilla, C.; Trejo-Avila, L.M. Sulphated polysaccharides from Ulva clathrata and Cladosiphon okamuranus seaweeds both inhibit viral attachment/entry and cell-cell fusion, in NDV infection. Mar. Drugs 2015, 13, 697-712. [CrossRef] [PubMed]

27. Trejo-Avila, L.M.; Morales-Martínez, M.E.; Ricque-Marie, D.; Cruz-Suarez, L.E.; Zapata-Benavides, P.; Morán-Santibañez, K.; Rodríguez-Padilla, C. In vitro anti-canine distemper virus activity of fucoidan extracted from the brown alga Cladosiphon okamuranus. Virusdisease 2014, 25, 474-480. [CrossRef] [PubMed]

28. Shi, Q.; Wang, A.; Lu, Z.; Qin, C.; Hu, J.; Yin, J. Overview on the antiviral activities and mechanisms of marine polysaccharides from seaweeds. Carbohydr. Res. 2017, 453-454, 1-9. [CrossRef] [PubMed]

29. Kim, E.; Kwak, J. Antiviral phlorotannin from Eisenia bicyclis against human papilloma virus in vitro. Planta Med. 2015, 81, 22. [CrossRef]

30. Ahn, M.J.; Yoon, K.D.; Min, S.Y.; Lee, J.S.; Kim, J.H.; Kim, T.G.; Kim, S.H.; Kim, N.G.; Huh, H.; Kim, J. Inhibition of HIV-1 reverse transcriptase and protease by phlorotannins from the brown alga Ecklonia cava. Biol. Pharm. Bull. 2004, 27, 544-547. [CrossRef] [PubMed]

31. Eom, S.H.; Moon, S.Y.; Lee, D.S.; Kim, H.J.; Park, K.; Lee, E.W.; Kim, T.H.; Chung, Y.H.; Lee, M.S.; Kim, Y.M. In vitro antiviral activity of dieckol and phlorofucofuroeckol-A isolated from edible brown alga Eisenia bicyclis against murine norovirus. Algae 2015, 30, 241-246. [CrossRef]

32. Wright, P.F.; Deatly, A.M.; Karron, R.A.; Belshe, R.B.; Shi, J.R.; Gruber, W.C.; Zhu, Y.; Randolph, V.B. Comparison of results of detection of rhinovirus by PCR and viral culture in human nasal wash specimens from subjects with and without clinical symptoms of respiratory illness. J. Clin. Microbiol. 2007, 45, 2126-2129. [CrossRef] [PubMed] 
33. Bahramsoltani, R.; Sodagari, H.R.; Farzaei, M.H.; Abdolghaffari, A.H.; Gooshe, M.; Rezaei, N. The preventive and therapeutic potential of natural polyphenols on influenza. Expert Rev. Anti-Infect. Ther. 2016, 14, 57-80. [CrossRef] [PubMed]

34. Al-Saif, S.S.A.; Abdel-Raouf, N.; Aref, I.A. Antibacterial substances from marine algae isolated from Jeddah coast of Red sea, Saudi Arabia. Saudi J. Biol. Sci. 2014, 21, 57-64. [CrossRef] [PubMed]

35. Namvar, F.; Mohamed, S.; Ghasemi, S.; Behravan, J. Polyphenol-rich seaweed (Eucheuma cottonii) extract suppresses breast tumour via hormone modulation and apoptosis induction. Food Chem. 2012, 130, 376-382. [CrossRef]

36. El-toumy, S.A.; Salib, J.Y.; El-kashak, W.A.; Marty, C.; Bedoux, G.; Bourgougnon, N. Antiviral effect of polyphenol rich plant extracts on herpes simplex virus type 1. Food Sci. Hum. Wellness 2018, 7, 91-101. [CrossRef]

37. Amoros, M.; Simóes, C.M.O. Synergistic effect of playones and flavonols against herpes simplex virus type 1 in cell culture. Comparison with the antiviral activity of propolis. J. Nat. Prod. 1992, 55, 1732-1740. [CrossRef] [PubMed]

38. Nakamura, T.; Nagavama, K.; Uchida, K. Antioxidant Activity from the Brown of Phlorotannins Isolated Alga Eisenia bicyclis. Nineteenth International Seaweed Symposium. Dev. Appl. Phycol. 1996, 62, 923-926.

39. Sugiura, Y.; Matsuda, K.; Okamoto, T.; Kakinuma, M.; Amano, H. Anti-allergic effects of the brown alga Eisenia arborea on Brown Norway rats. Fish. Sci. 2008, 74, 180-186. [CrossRef]

40. Kwon, H.J.; Ryu, Y.B.; Kim, Y.M.; Song, N.; Kim, C.Y.; Rho, M.C.; Jeong, J.H.; Cho, K.O.; Lee, W.S.; Park, S.J. In vitro antiviral activity of phlorotannins isolated from Ecklonia cava against porcine epidemic diarrhea coronavirus infection and hemagglutination. Bioorg. Med. Chem. 2013, 21, 4706-4713. [CrossRef] [PubMed]

(C) 2018 by the authors. Licensee MDPI, Basel, Switzerland. This article is an open access article distributed under the terms and conditions of the Creative Commons Attribution (CC BY) license (http:/ / creativecommons.org/licenses/by/4.0/). 